\title{
AN OVERVIEW USE OF ANALYTIC HIERARCHY PROCESS (AHP) IN DESIGN FOR REMANUFACTURING ACTIVITIES
}

\author{
Tajul Ariffin Abdullah* \\ Department of Manufacturing Design \\ Faculty of Manufacturing Engineering \\ Universiti Teknikal Malaysia Melaka, 76100 Durian Tunggal, Melaka, Malaysia \\ E-mail: tajul@utem.edu.my \\ Dzuraidah Abd. Wahab \\ Department of Mechanical and Materials Engineering \\ Faculty of Engineering and Built Environment \\ Universiti Kebangsaan Malaysia, 43600 Bangi, Malaysia \\ E-mail: dzuraida@eng.ukm.my \\ A.A.Lashlem \\ Department of Mechanical and Materials Engineering \\ Faculty of Engineering and Built Environment \\ Universiti Kebangsaan Malaysia, 43600 Bangi, Malaysia \\ E-mail: abobaker@vlsi.eng.ukm.my
}

\begin{abstract}
This paper gives an overview usage of Analytic Hierarchy Process (AHP) as a decision support model for selecting a set of Design for Remanufacturing (DfRem) criteria and assigns importance weightings into it to make a decision. Increasingly remanufacturing and recovers activities are gaining popularities among remanufacturers due to its potential value and sustainability get serious attention among the developed and developing countries as one of business arm for the nation. Although traditionally, the remanufacturing sectors was explored by small and independent manufacturers, but nowadays increases the number of original equipment manufacturers such as Xerox, Caterpillar, Kodak, Delphi as named it few are highly and actively involved on this field. Although, the remanufacturing sectors are expending, there is limited of literatures and theories on decision making for DfRem had been covered by academicians, industry players or researchers on this field. There is need for a decision making in product design as well as process design that address remanufacturing issues at early phase of product development. AHP can be incorporated into a comprehensive information system for supporting Design for Remanufacturing (DfRem) activities. An initial framework on decision making using AHP for DfRem is proposed based on literature findings and case studies inputs obtained from the local remanufacturers.
\end{abstract}

Keywords: Remanufacturing, Decision Support, Design for Remanufacturing, Analytic Hierarchy Process

\section{Introduction}

A growing interest on environmental and product sustainability demand research into the design of more remanufacturing benign products. Remanufacturing is an 'end-of-life' strategy that reduces the use of raw materials and energy to manufacture new products. Economically, remanufacture is an important strategy

\footnotetext{
${ }^{*}$ Corresponding author
} 
due to the fact it preserves the product's value added during the design and manufacturing processes. Based on environmental perspective, the interesting of remanufacture lies on extending the product's lifetime by diverting them into a second life, given that if a product lasts longer through remanufacturing, less material is needed to meet customer needs. The new product development has demanded product sustainability improvement without ignoring the potential of remanufacturing of existing product. According to Ijomah et al. (2007a) referred remanufacturing as the process of returning a used product to like-new condition with a warranty to match. The process remanufacturing includes activities such as sorting, inspection, disassembly, cleaning, reprocessing and reassembly. The detail concept of remanufacturing can be obtained the research work done by Seitz and Wells, (2006) and Sundin (2009). Lately, many organizations have adopted remanufacturing as a focus business strategy and by complying with legislation in a profitable manner (Webster and Mitra, 2007; King et al., 2006). It has been agreed by authors Wang and Cheng, (2011), and Milanez and Buhrs, (2009) that remanufacturing activities mainly offer profitable income as well as support an excellent mechanism to reduce the environmental impact of end-of-use-products. Walsh (2010) summarized remanufacturing as returning a used product via a manufacturing process at least its original performance with a warranty that is equivalent or better than that of the newly manufactured product. In general, the term or the process of remanufacturing get confused with other similar activities such as repairing, refurbishing and reconditioning. Repaired, refurbished and reconditioned products are very close to remanufactured ones and these terms can often be considered synonymous with each other (Ijomah et.al.2007b) Although in general those terms have similarities but in term functionality and performance brings different weightage and meanings as refferred in Table 1.

Table 1. Summary of Remanufacturing Terms and synonymous with each other (Ijomah et, al.2007)

\begin{tabular}{|l|l|}
\hline \multicolumn{1}{|c|}{ Terms } & \multicolumn{1}{|c|}{ Description } \\
\hline Recycling & $\begin{array}{l}\text { Processing used material into new products through } \\
\text { activities of discarding used materials into production } \\
\text { of different/same product }\end{array}$ \\
\hline Repairing & $\begin{array}{l}\text { Correction of specified faults in a product, when } \\
\text { repaired products have warranties, the warranty not } \\
\text { covering the whole product but only on the } \\
\text { component that has been replaced }\end{array}$ \\
\hline Refurbishing & $\begin{array}{l}\text { A used product, cleaned up, tested, repackaged and } \\
\text { made available for resale. A refurbished product has } \\
\text { some nonworking parts replaced to restore the } \\
\text { product to working condition, with warranty less than } \\
\text { that of a new product. }\end{array}$ \\
\hline Reconditioning & $\begin{array}{l}\text { A used product that is cleaned up and tested } \\
\text { extensively with possible repair before repackaged } \\
\text { for resale at a satisfactory working condition, } \\
\text { with warranty less than that of a newly manufactured } \\
\text { equivalent whereby the warranty applies to all major } \\
\text { wearing parts. }\end{array}$ \\
\hline Remanufacturing & $\begin{array}{l}\text { Returning a used (end-of-life) product to at least } \\
\text { OEM original performance specification from the } \\
\text { customer perspective. Product warranty is at least } \\
\text { equal to that of a newly manufactured equivalent. }\end{array}$ \\
\hline
\end{tabular}


To enhance the remanufacturing concerns, Design for Remanufacturing (DfRem) has spurred among the product remanufacturer due to advantages offered at early product design stage that influence manufacturing cost and overall product life span. A doing right for the first time is essential for any product development in order to be survival in future as well as comply with product sustainability until end-of- life cycle. It is vital for design engineers to address the remanufacturing challenges issues as early as possible of product usage. DfRem is adopted to address issues on ease of remanufacturing processes such as disassembly and reassembly of a product. When product design gets more complicated and varies, decision making is vital to determine which remanufacturing activities to consider first and what are rules to follow either it can be easy to be remanufactured or not. Therefore, Analytic Hierarchy Process (AHP) is suggested for Design for remanufacturing factors selection at early product design phases.

\section{Design for Remanufacturing (DfRem)}

Nowadays, Design for Remanufacturing (DfRem), has received relatively high levels of interest in an area of remanufacturing activities due to the recognition that a product's design that have a high impact on product's lifespan such as cost, manufacturing and end-of-life possibilities. The potential advantages of remanufacturing can be substantial. It can be seen on the cost reduction of a remanufactured product have been estimated at 30-60\% or can be more and it depends on nature of product itself. Moreover, it is expected the knowledge of part failure gained through a product return cycle can result in less expensive part design, fewer failure modes, decreased repair costs, and ultimately provide the customer with improved quality products. According to Ijomah et al., (2007b), DfRem is referred as a design activity how remanufactured factors are concerned in product design and how to overcome the technical barriers as remanufacturing concern. On the other hand, DfRem is also considered to be a distinct design activity that involves in addressing various design issues relating to remanufacturing. Furthermore, DfRem is generally viewed as a combination of design process that accommodate with product strategy with detail of product engineering that can be remanufactured. In addition, DfRem could involve in making decisions such as standardizing parts or selecting a more durable material to optimize the remanufacturing process. DfRem also seen as a concurrent engineering tool, design for ' $\mathrm{X}$ ' (DfX), addressing different issues and elements simultaneously (Charter and Gray, 2008; Sundin (2004). Researchers like Casper and Martin (2007) listed the Design for ' $X$ ' strategies with their corresponding remanufacturing steps as shown in Table 2. 
Table 2. Design for ' $\mathrm{X}$ ' strategies with their corresponding remanufacturing steps (Casper \& Martin 2007)

\begin{tabular}{|c|c|c|c|c|c|c|c|}
\hline \multirow[b]{2}{*}{ Design strategy } & \multicolumn{7}{|c|}{ Remanufacturing Process } \\
\hline & 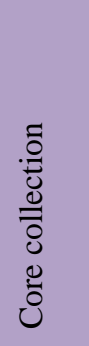 & 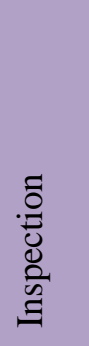 & 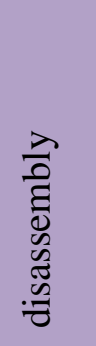 & 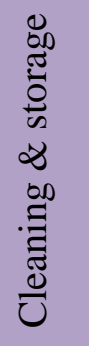 & 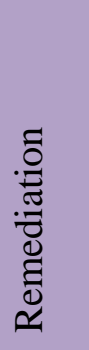 & 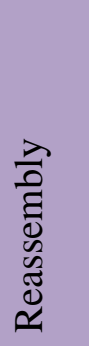 & $\stackrel{\infty}{\Xi}$ \\
\hline $\begin{array}{l}\text { Design for core } \\
\text { collection }\end{array}$ & $*$ & 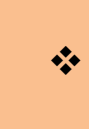 & & & & & \\
\hline Eco-design & & 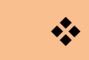 & $\nLeftarrow$ & $*$ & & 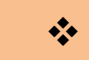 & \\
\hline Design for assembly & & $*$ & $\nLeftarrow$ & $*$ & $*$ & $\nLeftarrow$ & \\
\hline $\begin{array}{l}\text { Design for multiple } \\
\text { lifecycle }\end{array}$ & & & & $*$ & $*$ & & \\
\hline Design for upgrade & & & & & 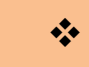 & & \\
\hline Design for evaluation & & $\%$ & & & & & $*$ \\
\hline
\end{tabular}

\subsection{Design for Remanufacturing (DfRem) associate with Tools and Methods}

At present, most of the DfRem research activities has involved in addressing of remanufacturing issues that associate with product design, and the subsequent development of design aids; tools, methods and approaches that are designed to alleviate these problems still early at the product development stage. It also agreed that the establishment of software development for application on DfRem is considered at infant stage and did not mature enough to address design for remanufacturing issues comprehensively and its effectiveness can be arguable. Some organization such as Green Engineering Corp. has developed software on addressing issues on diassemblability, reusability that determines material choices; energy and pollutant savings; cost disassembly and materials in other products. Furthermore, Boothroyd Dewhurst Inc. also developed software such as "design for service" and "design for disassembly/environment". Besides that for assessment purposes several databases such as Recycling Oriented Database Analysis (RONDA), Recycling, Resources, and Technologies Information 
(RECREATION), and Remanufacturing Cost Optimization via Extended Reuse and Disassembly (RECOVERY) are also created (David G. Mabee,et al., 1999). In addition, the Table 3 indicates the summary of design aids as an either in the form of software tools, mathematical models or decision making (G.D. Hatcher et al., 2011). As a general, those design aids as their own limitation and restriction.

Table 3. Summary of DfRem design aids in the literature.( G.D. Hatcher et al., 2011)

\begin{tabular}{|c|c|c|c|c|c|c|c|c|}
\hline NO. & APPROACH & AUTHOR(S) & $\begin{array}{l}\text { FORMAT } \\
\text { STYLE }\end{array}$ & KEY PURPOSE & $\begin{array}{l}\text { DESIGN } \\
\text { STAGE }\end{array}$ & ADVANTAGES & DISADVANTAGES & $\begin{array}{l}\text { USEIN } \\
\text { INDUSTRY }\end{array}$ \\
\hline 1. & Modularisation & $\begin{array}{l}\text { Ishii et al. } \\
(1994) ; \\
\text { Kimura et } \\
\text { al. (2001) }\end{array}$ & Concept & $\begin{array}{l}\text { Traditional: } \\
\text { improve } \\
\text { manufacturing } \\
\text { efficiency. } \\
\text { Reman: ease for } \\
\text { disassembly }\end{array}$ & $\begin{array}{l}\text { Concept } \\
\text { develop }\end{array}$ & Familiar concept. & $\begin{array}{l}\text { - Notholistic. } \\
\text { - Noguidance }\end{array}$ & Yes \\
\hline 2. & FMEA & $\begin{array}{l}\text { Lam etal. } \\
(2000) ; \\
\text { Sherwood } \\
(2000)\end{array}$ & $\begin{array}{l}\text { Paper/ } \\
\text { software }\end{array}$ & $\begin{array}{l}\text { Traditional: } \\
\text { prioritise and } \\
\text { prevent product } \\
\text { failure. } \\
\text { Reman: reduce } \\
\text { waste. }\end{array}$ & $\begin{array}{l}\text { Concept } \\
\text { develop }\end{array}$ & $\begin{array}{l}\text { - Familiar } \\
\text { concept. } \\
\text { - Lifecycle } \\
\text { thinking. } \\
\text { - Process } \\
\text { oriented }\end{array}$ & $\begin{array}{l}\text { Relate on OEM } \\
\text { feedback }\end{array}$ & Yes \\
\hline 3. & $\begin{array}{l}\text { Active } \\
\text { disassembly }\end{array}$ & $\begin{array}{l}\text { Chiodo and } \\
\text { ljomah } \\
(2009)\end{array}$ & Concept & $\begin{array}{l}\text { Efficient } \\
\text { disassembly. }\end{array}$ & $\begin{array}{l}\text { Concept } \\
\text { develop }\end{array}$ & Process oriented & Notholistic & No \\
\hline 4. & $\begin{array}{l}\text { Design for } \\
\text { environment } \\
\text { tools } \\
\end{array}$ & $\begin{array}{l}\text { Pigosso et } \\
\text { al. (2009) }\end{array}$ & Various & $\begin{array}{l}\text { Improve } \\
\text { environmental } \\
\text { performance. }\end{array}$ & Various & Lifecycle thinking & $\begin{array}{l}\text { - Notholistic. } \\
\text { - Complex }\end{array}$ & No \\
\hline 5. & QFD & $\begin{array}{l}\text { Yuksel } \\
(2010)\end{array}$ & $\begin{array}{l}\text { Paper/ } \\
\text { software }\end{array}$ & $\begin{array}{l}\text { Traditional: } \\
\text { consider voice of } \\
\text { the customer to } \\
\text { meet their needs. } \\
\text { Reman: consider } \\
\text { voice of the } \\
\text { remanufacturer. }\end{array}$ & $\begin{array}{l}\text { Concept } \\
\text { develop }\end{array}$ & $\begin{array}{l}\text { - Familiar } \\
\text { concept. } \\
\text { - Process } \\
\text { oriented }\end{array}$ & $\begin{array}{l}\text { Reliant on OEM } \\
\text { feedback }\end{array}$ & Yes \\
\hline
\end{tabular}

Generally, the principles and requirement for DfRem is associated with pillars and terms relate to product assembly, disassembly, sorting, cleaning, inspection, testing, refurbishing, repair, replacement, reassembly and packaging. Each of the terms and attributes are explained further by Table 4 and 5 respectively. The attributes tend to be as a checklist at early stage in product design before any products to be remanufactured.

Table 4. Terms and Attributes for DfRem- Part 1 (David. G.M.,1999)

\begin{tabular}{|c|c|c|c|}
\hline No. & Terms & Objective & Attributes \\
\hline 1. & Disassembly & $\begin{array}{l}\text { to minimize total } \\
\text { disassembly time } \\
\text { by decreasing the } \\
\text { number } \\
\text { complexity and } \\
\text { disassembly steps }\end{array}$ & $\begin{array}{l}\text { Access to Subsystem } \\
\text { time to remove items for access } \\
\text { number of steps } \\
\text { Subsystem Remof items to remove for access } \\
\text { layout/instructions provided } \\
\text { time to remove subsystem } \\
\text { number of fasteners to remove subsystem } \\
\text { mounting points are easily accessible } \\
\text { mounting points are easily identified } \\
\text { number of tools used used } \\
\text { removal without damage } \\
\text { quantify parts damage }\end{array}$ \\
\hline
\end{tabular}




\begin{tabular}{|c|c|c|c|}
\hline & & & 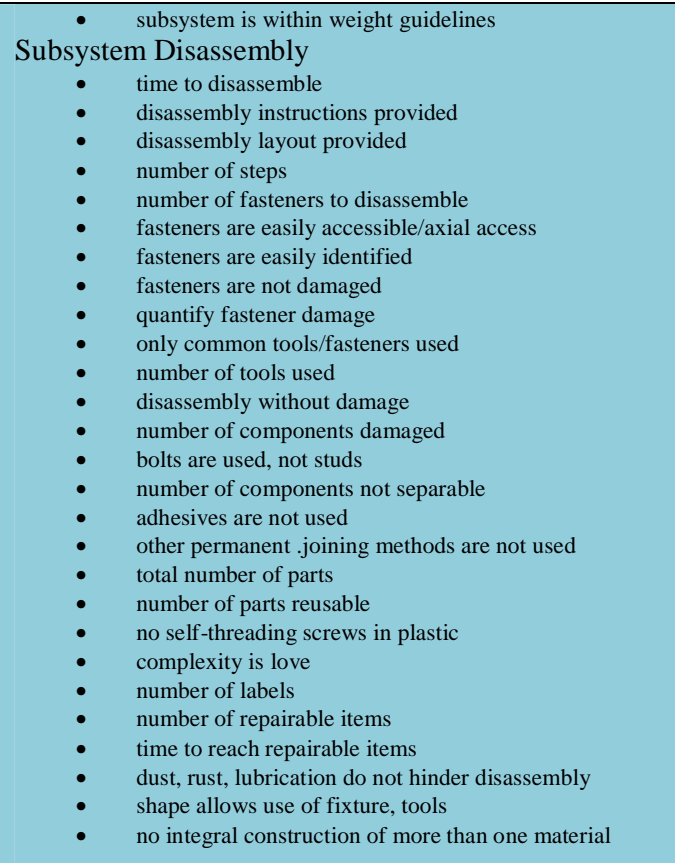 \\
\hline 2. & Sorting & $\begin{array}{lr}\text { To identify } & \text { either } \\
\text { by visual and } & \text { andional } \\
\text { function } & \text { to } \\
\text { determine } & \\
\text { components that are } \\
\text { physically different } \\
\text { identify good } \\
\text { versus railed } \\
\text { components. }\end{array}$ & $\begin{array}{l}\text { Visual or Functional Sorting } \\
\quad \text { wear and corrosion is easily detected } \\
\text { parts are marked with material composition } \\
\text { number of uses are marked } \\
\text { tools are not required for visual sorting } \\
\text { all similar parts are clearly identified } \\
\text { or marked for easy sorting } \\
\text { number of materials } \\
\text { part specification/failure criteria provided } \\
\text { part test procedure provided } \\
\text { part test is simple } \\
\text { time to perform test/apply criteria } \\
\text { part life/wear indicator available } \\
\text { subjective sorting is not required } \\
\text { how many scrapped materials do not require } \\
\text { further disassembly for recycling } \\
\end{array}$ \\
\hline 3. & Cleaning & $\begin{array}{l}\text { To identify cleaning } \\
\text { method is selected } \\
\text { is simple and cost } \\
\text { effective }\end{array}$ & $\begin{array}{l}\text { time to clean } \\
\quad \text { total cleaning material used } \\
\quad \text { notal waste generated } \\
\text { number of parts needing cleaning } \\
\text { number of cavities difficult to clean } \\
\text { number of corners difficult to clean } \\
\text { labels withstand cleaning process } \\
\text { markings withstand cleaning process } \\
\text { environmentally friendly cleaning agents only } \\
\text { surfaces to be cleaned are smooth } \\
\text { surfaces are wear resistant } \\
\text { deposits, impurities are removable without part damage } \\
\text { standard cleaning methods only } \\
\text { no paper labels removed, \# } \\
\text { method of cleaning provided, specified } \\
\quad \text { number/cost of parts not cleanable } \\
\end{array}$ \\
\hline
\end{tabular}


Table 5. Terms and Attributes for DfRem- Part II (David. G.M.,1999)

\begin{tabular}{|c|c|c|c|}
\hline No. & Terms & Objective & Attributes \\
\hline 1. & Refurbishment & $\begin{array}{l}\text { To return product } \\
\text { component to a } \\
\text { like-new } \\
\text { performance. }\end{array}$ & 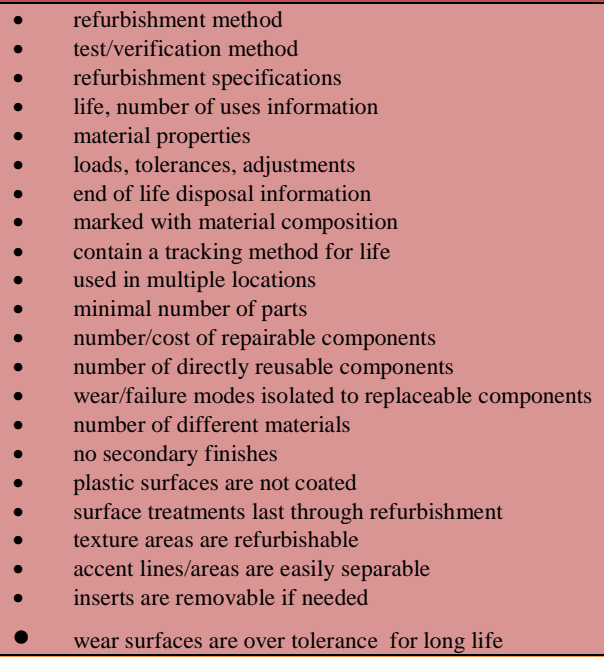 \\
\hline 2. & Test & $\begin{array}{l}\text { To determine } \\
\text { performance of the } \\
\text { product or } \\
\text { component }\end{array}$ & $\begin{array}{ll}* & \text { simple, quick } \\
* & \text { objective replacement criteria } \\
* & \text { common test fixtures/tools }\end{array}$ \\
\hline 3. & Reassembly & $\begin{array}{l}\text { To adjustments } \\
\text { being easy to make, } \\
\text { flexible, adopt new } \\
\text { immigration } \\
\text { technology and } \\
\text { independent from } \\
\text { each other. }\end{array}$ & $\begin{array}{ll} & \text { number of adjustments } \\
& \text { adjustments are independent } \\
\text { time to reassemble } \\
\quad \text { time to verify performance } \\
\quad \text { method to verify performance provided } \\
\quad \text { objective criteria for performance verification } \\
\quad \text { upgraded configurations assemble without modification }\end{array}$ \\
\hline
\end{tabular}

\section{Analytical Hierarchy Process (AHP) and Attributes}

Analytical Hierarchy Process (AHP) is one of the decisions making powerful tool that was first developed within the management science field more than 20 years (Saaty, 1980). According to Saaty (2008), AHP is referred as a theory of measurement through pairwise comparisons and relies on the judgements of experts to derive priority scales that measure intangibles in relative terms. Comparisons are made using a scale of absolute judgements that represents, how much more, one element dominates another with respect to a given attribute and Table 6 exhibits the scale. The judgements may be inconsistent, and how to measure inconsistency and improve the judgements, when possible to obtain better consistency is a concern of the AHP. The derived priority scales are synthesised by multiplying them by the priority of their parent nodes and adding for all such nodes. The AHP has been used in a wide range of contexts for decision making that incorporate hard-to-quantify decision factors. The aim of AHP tool is to support decision maker make more effective decisions by structuring and evaluating the relative attractiveness of competing options or alternatives by translate the preferential judgements. In addition, the AHP supposes that it is easier for an expert decision-maker to compare the importance of two parameters than to state directly the generic by preferential hierarchy. 
Table 6. The fundamental scale of absolute numbers (Saaty, 2008)

\begin{tabular}{|c|c|c|}
\hline $\begin{array}{l}\text { Intensity of } \\
\text { Importance }\end{array}$ & Definition & Explanation \\
\hline 1 & Equal Importance & $\begin{array}{l}\text { Two activities contribute equally to } \\
\text { the objective }\end{array}$ \\
\hline 2 & Weak or slight & \\
\hline 3 & Moderate importance & $\begin{array}{l}\text { Experience and judgement slightly } \\
\text { favour one activity over another }\end{array}$ \\
\hline 4 & Moderate plus & \\
\hline 5 & Strong importance & $\begin{array}{l}\text { Experience and judgement strongly } \\
\text { favour one activity over another }\end{array}$ \\
\hline 6 & Strong plus & \\
\hline 7 & Very strong or demonstrated importance & $\begin{array}{l}\text { An activity is favoured very strongly } \\
\text { over another; its dominance } \\
\text { demonstrated in practice }\end{array}$ \\
\hline 8 & Very, very strong & \\
\hline 9 & Extreme importance & $\begin{array}{l}\text { The evidence favouring one activity } \\
\text { over another is of the highest } \\
\text { possible order of affirmation }\end{array}$ \\
\hline Reciprocals of above & $\begin{array}{l}\text { If activity } i \text { has one of the above non-zero } \\
\text { numbers assigned to it when compared with } \\
\text { activity } j \text {, then } j \text { has the reciprocal value when } \\
\text { compared with } i\end{array}$ & A reasonable assumption \\
\hline $1.1-1.9$ & If the activities are very close & $\begin{array}{l}\text { May be difficult to assign the best } \\
\text { value but when compared with other } \\
\text { contrasting activities } \\
\text { the size of the small numbers would } \\
\text { not be too noticeable, yet they can } \\
\text { still indicate the relative importance } \\
\text { of the activities. }\end{array}$ \\
\hline
\end{tabular}

The AHP method is applied in situations when a hierarchy of objectives exists. AHP utilizes pair-wise comparisons for a set of criteria to judge the relative importance of one criterion to another. AHP combines the information from these comparisons to establish a weight for each criterion. AHP may also be applied to each criterion to develop weights for each measure. The AHP can be sub divided into various actions such as to allows a systematic consideration of the problem by identifying all the important factors that may influence a particular decision alternative and support of both quantitative and qualitative factors in the decision-making process beside allows to break down a complex problem into sub problems by systematically analysing the sub problems. Furthermore, a multicriteria decision making method (MCDM), can be employed as an AHP balances the interactions among decision criteria and synthesizes the information into a vector of preferences among the alternatives (Saaty, 2008). As a fundamental the AHP can be summarized addressing three functions namely structuring complexity, measuring on ratio scale and synthesizing. To make a decision in an organized way to generate priorities need to decompose the process flow as shown by Figure 1. 


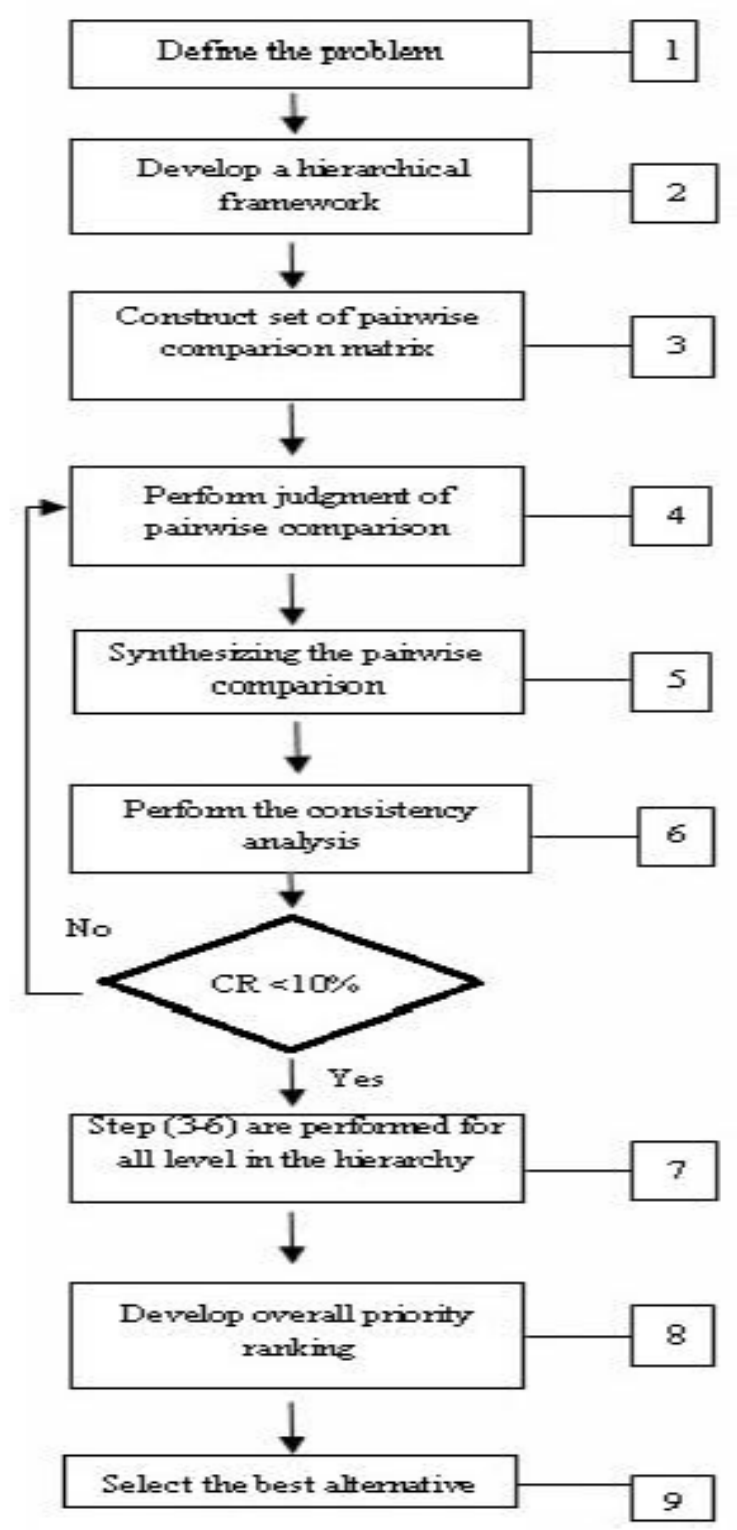

Figure 1. Process Flow of AHP (Hambali A., 2009)

The real strength of AHP is clearly though that it treats the decision as a system, which is difficult for many decision-makers to do. Bounded rationality and limited cognitive processes make it nearly impossible for the decision-maker to adequately consider all of the factors involved in a complex screening decision. Without decision tools like AHP, decision makers might base their decisions on only a subset of important criteria while not understanding their relative weights and interactions. By using the AHP makes complex decision processes more rational by synthesizing all. The various applications on usage of AHP as an decision making can referred literature work done by authors such as Sarkis (2003); Gaudenzi and Borghesi (2006) ; Lee and Kozar (2006); Chan et al.( 2006); Chang et al. (2007); 
Korpela et al. 2007); Ramanathan (2007); Da gdeviren (2008); Zayed et al. 2008); Sharma and Agrawal (2009); Chan and Chan (2010) and Sarminento and Thomas (2010).

\section{A Case Study}

A case study is conducted one of the local remanufacturer that involves remanufacturing activities on engine blocks for crankshaft components. Based on data collection, six types of defects had been identified; known as crack, crooked, profile, dented, scratch and clogged. Based on Figure 2 there are six stages or divisions that have been separated according from level 1 until level 6 . Those six stages are exhibiting the common defects for crankshaft. Level 1 will be the major cause of defect for crankshaft, followed by level 2, level 3, level 4, level 5 and level 6 . Level 6 is for the minor defect for crankshaft before the crankshaft does the remanufacturing process.

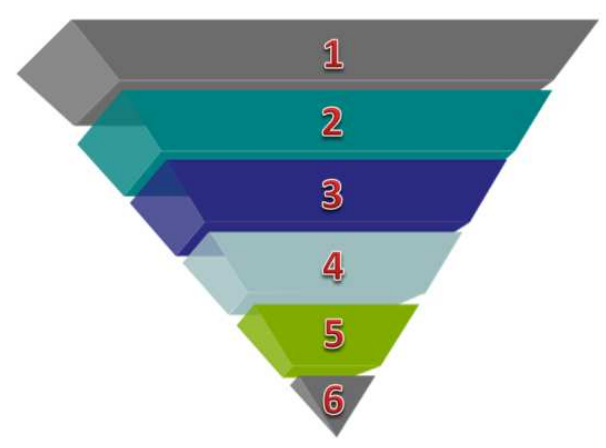

Figure 2. Hierarchical model

Figure 3 shows the type of defects and portion identified for crankshaft. The highest defect is clogged and the lowest is profile.

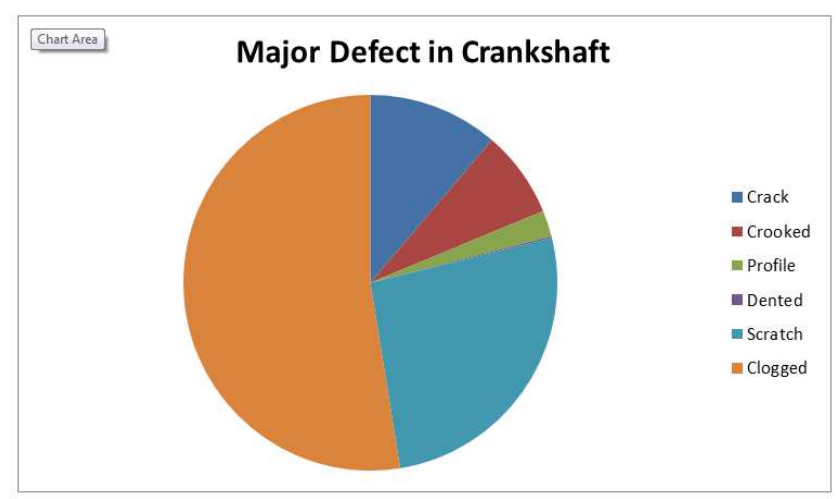

Figure 3.Major defects in crankshaft 


\section{T. Ariffin Abdullah et al.,/ design for remanufacturing activities}

After identified the defects, Hierarchical structure is developed based on remanufacturing requirement as shown by Figure 4. There are four levels involved in this framework. It is based selection of critical defects that associate with cost, resources \& skills, product characteristics and handling.

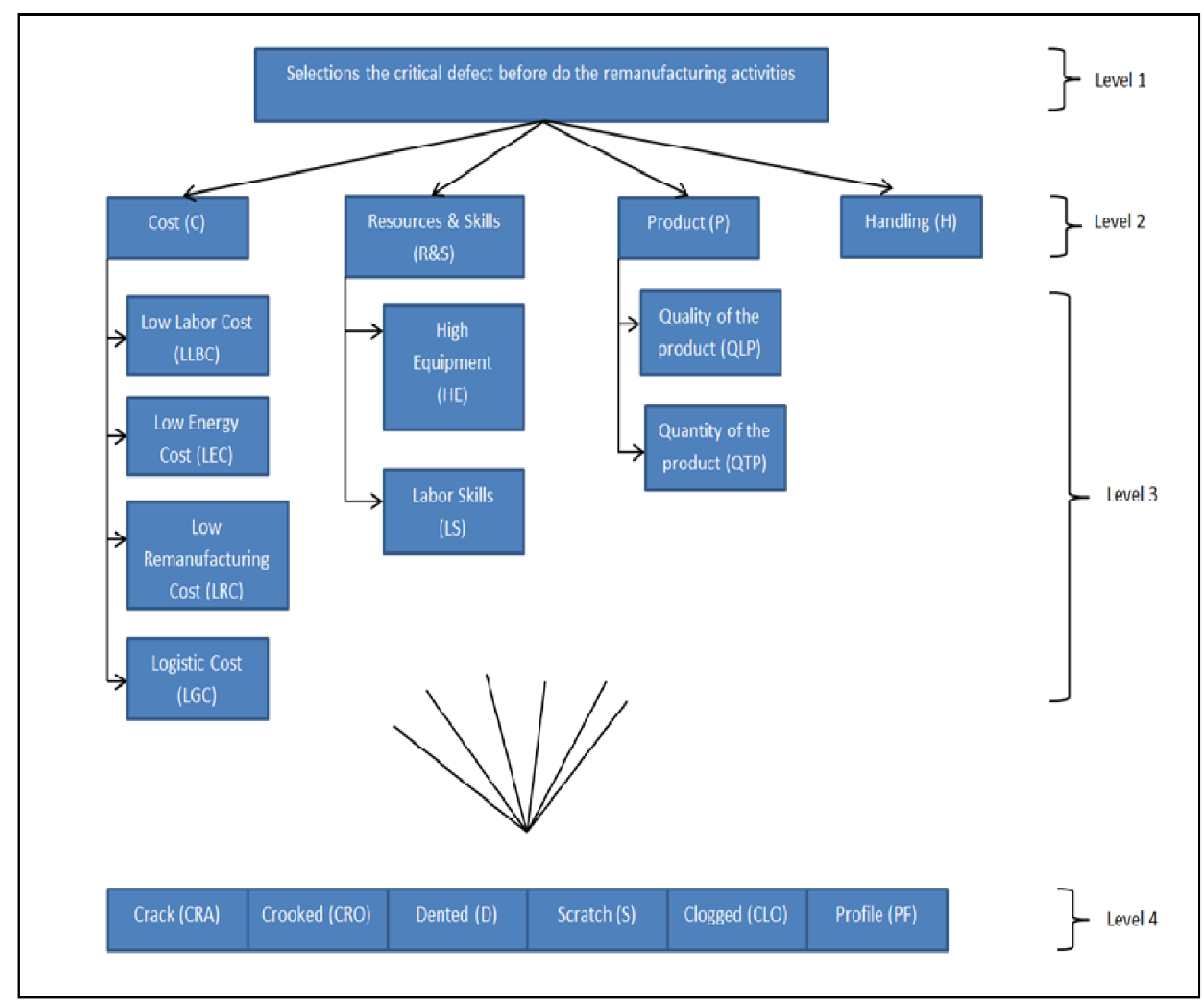

Figure 4. Hierarchical structures for selecting the critical defect in crankshaft

Level 1, represents the objective or the overall goal of the decision is presented at the top of the hierarchical structure. In this study, the overall goal is to select the critical defect for crankshaft before conducting remanufacturing activities. The second level represents the main criteria that can be classified into 4 parameters that are cost $(\mathrm{C})$, resources and skills $(\mathrm{R} \& \mathrm{~S})$, product characteristics $(\mathrm{P})$ and handling (H). The third level is referring to cost, the sub-criteria which are low labor cost (LLBC), low energy cost (LEC), low remanufacturing cost (LRC), logistic cost (LGC). The sub-criteria for Resources and skills are high equipment (HE) and labor skills (LS). While the sub-criteria for product (P) is quality of the product (QLP) and quantity of the product (QTP). Finally, the level 4 represent the critical defects. 


\section{Conclusion}

Although DfRem is considered relevant to the enhancement of remanufacturability, there is still need to be explored more with integration with tools and methods making DfRem more workable. The use of AHP as a decision making it makes the integration of DfRem process much simpler. Also, these methods have widely appreciated benefits with the interest of remanufacturer it also assist to reduce manufacturing costs and simplify the product development process. Although, as these approaches have not been developed in detailed yet but the framework is proposed as an apparent shift to conduct further work on remanufacturing activity.

\section{Acknowledment}

The authors would like to express their thanks to Ministry of Higher Education of Malaysia and Universiti Teknikal Malaysia Melaka (UTeM) for financial support of this research.

\section{REFERENCES}

Casper G. and Martin C. (2007). Remanufacturing and Product Design, The Centre for Sustainable Design, University College for the Creative Arts, Farnham, UK.

Chan, F.T.S., Chan, H.K..(2010). An AHP model for selection of suppliers in the fast changing fashion market. International Journal of Advanced Manufacturing Technology, 51 (9-12), 1195-1207.

Chan, F.T.S.,Chan,H.K.,Lau,H.C.W.,Ip,R.W.L.(2006).Benchmarkinglogistics performance of the postal industry - a double AHP approach. Benchmarking: An International Journal, 13(6),636-661.

Chang, C.-W., Wu, C.-R., Lin, C.-T., Chen, H.-C.(2007). An application of AHP and sensitivity analysis for selecting the best slicing machine. Computers \& Industrial Engineering, 52 (2), 296-307.

Charter, M. and Gray, C. (2007). Remanufacturing and product design: designing for the 7th generation, Centre for Sustainable Design, Farnham, Surrey, U.K.

Charter, M., Gray, C.(2008). Remanufacturing and product design. International Journal of Product Development, 6 (3-4), 375-392.

Da gdeviren,D.(2008).Decision making in equipment selection: an integrated approach with AHP and PROMETHEE. Journal of Intelligent Manufacturing, 19 (4), 397-406.

David G. M., Michael B., William D. K.(1999). Design Charts for Remanufacturing Assessment. Journal of Manufacturing Systems, 18(5), 358-366.

Gaudenzi, B., Borghesi, A.(2006). Managing risks in the supply chain using the AHP method. International Journal of Logistics Management, 17 (1), 114-136.

Hambali A.(2009). Application of Analytical Hierarchical Process in the Design Concept Selection of Automotive Composite Bumper Beam during the Conceptual Design Stage. PhD Thesis,Universiti Putra Malaysia, Malaysia. 


\section{T. Ariffin Abdullah et al.,/ design for remanufacturing activities}

Hatcher, G.D, Ijomah, W.L., Windmill, J.F. C.(2011). Design for remanufacture: a literature review and future research needs. Journal of Cleaner Production, 19 (17-18), 2004-2014.

Ijomah, W.L., McMahon, C., Hammond, G., Newman, S.(2007b). Development of design for remanufacturing guidelines to Support sustainable manufacturing. Robotics and Computer Integrated Manufacturing 23, 712-719.

Ijomah,W.L., McMahon, C., Hammond, G., Newman, S.(2007a). Development of robust design-forremanufacturing guidelines to further the aims of sustainable development. International Journal of Production Research, 45 (18), 4513-4536.

King, A., Burgess, S., Ijomah, W., McMahon, C.(2006). Reducing waste: repair, recondition, remanufacture or Recycle? Sustainable Development 14, 257-267.

Korpela, J., Lehmusvaara, A., Nisonen, J.(2007). Warehouse operator selection by combining AHP and DEA methodologies. International Journal of Production Economics, 108 (1-2), 135-142.

Lee, Y., Kozar, K.A.(2006). Investigating the effect of website quality on e-business success: an analytic hierarchy process (AHP) approach. Decision Support Systems, 42 (3), 1383-1401.

Milanez, B., Bührs, T.(2009). Extended producer responsibility in Brazil: the case of Mu, E. (2006). A unified framework for site selection and business forecasting using ANP. Journal of Systems Science and Systems Engineering, 15(2), 178-188.

Ramanathan, R.(2007). Supplier selection problem: integrating DEA with the approaches of total cost of ownership and AHP. Supply Chain Management: An International Journal, 12 (4), 258-261.

Saaty T.L.(2008). Decision making with the analytic hierarchy process. International Journal of Services Sciences, 1(1):83-98.

Sarkis, J.(2003). A strategic decision framework for green supply chain management. Journal of Cleaner Production 11 (4), 397-409.

Sarminento, R., Thomas, A.(2010). Identifying improvement areas when implementing green initiatives using a multitier AHP approach. Benchmarking: An International Journal, 17 (3), 452-463.

Seitz, M., Wells, P.(2006). Challenging the implementation of Corporate Sustainability: the case of automotive engine remanufacturing. Business Process Management, 12 (6), 822-836.

Sharma, S., Agrawal, N.(2009). Selection of a pull production control policy under different demand situations for a manufacturing system by AHP-algorithm. Computers \& Operations Research, 36 (5), $1622-1632$.

Sundin, E. (2004). Product and Process Design for Successful Remanufacturing. PhD Dissertation, Linkopings Universitet, Linkoping.

Sundin, E., Lindahl, M., Ijomah, W.L. (2009). Product design for product/ service systems: design experiences from Swedish industry. Journal of Manufacturing Technology Management, 20 (5), 723-753. tyre waste. Journal of Cleaner Production, 17 (6), 608-615. 
Walsh,B. (2010). PSS for Product Life Extension through Remanufacturing, CIRP IPS2 Conference 2010, 261-266.

Wang, X., Cheng, M.(2011). Implementing extended producer responsibility: vehicle remanufacturing in China. Journal of Cleaner Production, 19, 680-686.

Webster, S., Mitra, S.(2007). Competitive strategy in remanufacturing and the impact of take-back Laws. Journal of Operations Management, 25, 1123-1140.

Zayed, T., Amer, M., Pan, J.(2008). Assessing risk and uncertainty inherent in Chinese highway projects using AHP. International Journal of Project Management, 26 (4), 408-419. 